\title{
Semnificația sindromului de citoliză sever în cardiomiopatia hipertrofică la copil
}

\author{
Flavia-Cristina Al-Akel ${ }^{1}$, Amalia Făgărăşan ${ }^{2,3}$ \\ ${ }^{1}$ Clinica de Pediatrie 1, Spitalul Clinic Judeţean de Urgenţă, Târgu Mureş, România \\ ${ }^{2}$ Universitatea de Medicină, Târgu Mureş, România \\ ${ }^{3}$ Departamentul de Cardiologie Pediatrică, Institutul de Urgenţă pentru Boli Cardiovasculare şi \\ Transplant Târgu Mureş, România
}

\begin{abstract}
REZUMAT
Cardiomiopatia hipertrofică ocupă locul doi ca incidenţă între cardiomiopatiile copilului şi reprezintă o boală cu substrat genetic într-un procent semnificativ de cazuri, cu mare variabilitate în tabloul clinic. Boala apare la toate grupele de vârstă şi, nediagnosticată în timp util, poate avea prognostic imprevizibil.

Prezentăm cazul unui copil mic, de sex masculin, de doi ani şi jumătate, depistat la nivel teritorial cu suflu sistolic, afirmativ cu oboseală minimă, la care examenul ecocardiografic a decelat o cardiomiopatie hipertrofică obstructivă şi un mic defect septal atrial. Analizele de laborator au arătat un sindrom de citoliză sever, progresiv, testele genetice efectuate infirmând o distrofie musculară Duchenne sau boli de stocaj a glicogenului, de tip II Boala Pompe. Testele serologice pentru virusuri cu tropism hepatic au fost negative, iar examinările hematologice au infirmat o patologie din sfera hemato-oncologică.

Particularitatea acestui caz constă în discrepanţa dintre sindromul de citoliză sever şi prezentarea clinică oligosimptomatică.
\end{abstract}

Cuvinte cheie: cardiomiopatie hipertrofică, sindrom de citoliză, copil

\section{INTRODUCERE}

Cardiomiopatia hipertrofică $(\mathrm{CMH})$ este o boală miocardică ce se caracterizează prin îngroşarea semnificativă a ventriculului stâng, cu disfuncție diastolică, fiind cauzată de cele mai multe ori de o mutație în genele care codifică proteinele sarcomerului miocardic (gena lanțului greu al $\beta$ miozinei cardiace). În 30-60\% dintre cazuri boala se transmite genetic, ca o trăsătură autozomal dominantă, celelalte cazuri având caracter sporadic (1). Este foarte important să menţionăm heterogenitatea extremă a acestei boli: în momentul de faţă, există 15 gene ce codifică proteinele contractile sarcomerice (miozina, tropomiozina), care pot suferi mutații. Aceste gene sunt localizate pe 16 cromozomi diferiți, putând atinge peste 400 de mutații (2). Pe de altă parte, copiii proveniți din mame diabetice se pot naşte cu această patologie cardiacă, existând date care atestă o prevalență de 10-20\%. Prognosticul bolii depinde de cauza care a determinat anomalia.
În tabloul paraclinic al oricărei cardiomiopatii hipertrofice, indiferent de cauza care a determinat-o, se regăsesc elemente tipice sindromului de citoliză.

În practica medicală pediatrică, trebuie acordată o atenție sporită severitătii acestui sindrom de citoliză, deoarece spectrul etiologic este vast şi multe afecțiuni autoimune, metabolice, infecțioase pot genera valori persistent crescute ale markerilor de citoliză, punând probleme serioase de diagnostic şi tratament.

Conform unui studiu recent efectuat de doctor Trandafir L. şi colaboratorii pe un lot de 394 de copii, cu vârste cuprinse între 1,5 luni şi 16 ani, sindromul de citoliză la copil este relativ frecvent întâlnit, având o etiologie multifactorială. Acest studiu a arătat că etiologia sindromului de citoliză este dominată de infecțiile acute respiratorii, digestive, urinare, urmate de infecțiile virale (virusul Epstein Barr şi citomegalovirus). De asemenea, se citează infecțiile parazitare, obezitatea sau excesul ponderal şi bolile de nutriție şi metabolism. În 20,31\% dintre cazuri, etiologia nu a fost elucidată, posibilităţile de explorare serologică fiind limitate (3). 


\section{PREZENTARE DE CAZ}

Prezentăm cazul unui copil mic în vârstă de doi ani şi jumătate, de sex masculin, depistat cu un suflu sistolic şi admis în departamentul de cardiologie pediatrică pentru stabilirea etiologiei suflului. Antecedentele heredocolaterale şi personale sunt fără semnificație clinică.

Examenul obiectiv a pus în evidenţă un copil stabil hemodinamic, fără deficit staturo-ponderal, fără stigme genetice, fără retard neuro-psiho-motor sau deficiențe motorii, cu paloare muco-tegumentară discretă, iar la examinarea aparatului cardio- vascular s-au decelat următoarele elemente: alura ventriculară (AV) 98/min, suflu sistolic grad II/6, tensiune arterială $90 / 55 \mathrm{mmHg}$, saturația oxigenului în aerul ambiental 98\%. Diagnosticul ecocardiografic: cardiomiopatie hipertrofică obstructivă concentrică - cu gradient medio-ventricular, insuficiență mitrală uşoară, mic defect septal atrial restrictiv (Fig. 1 şi 2).

Examinările paraclinice au arătat teste funcționale hepatice cu valori crescute, alanin aminotransferaza (ALT) şi aspartat aminotransferaza (AST): ALT 184-277 U/1 (de 5-6 ori valoarea normală) şi AST 240-331 U/1 (de 9-10 ori valoarea normală).

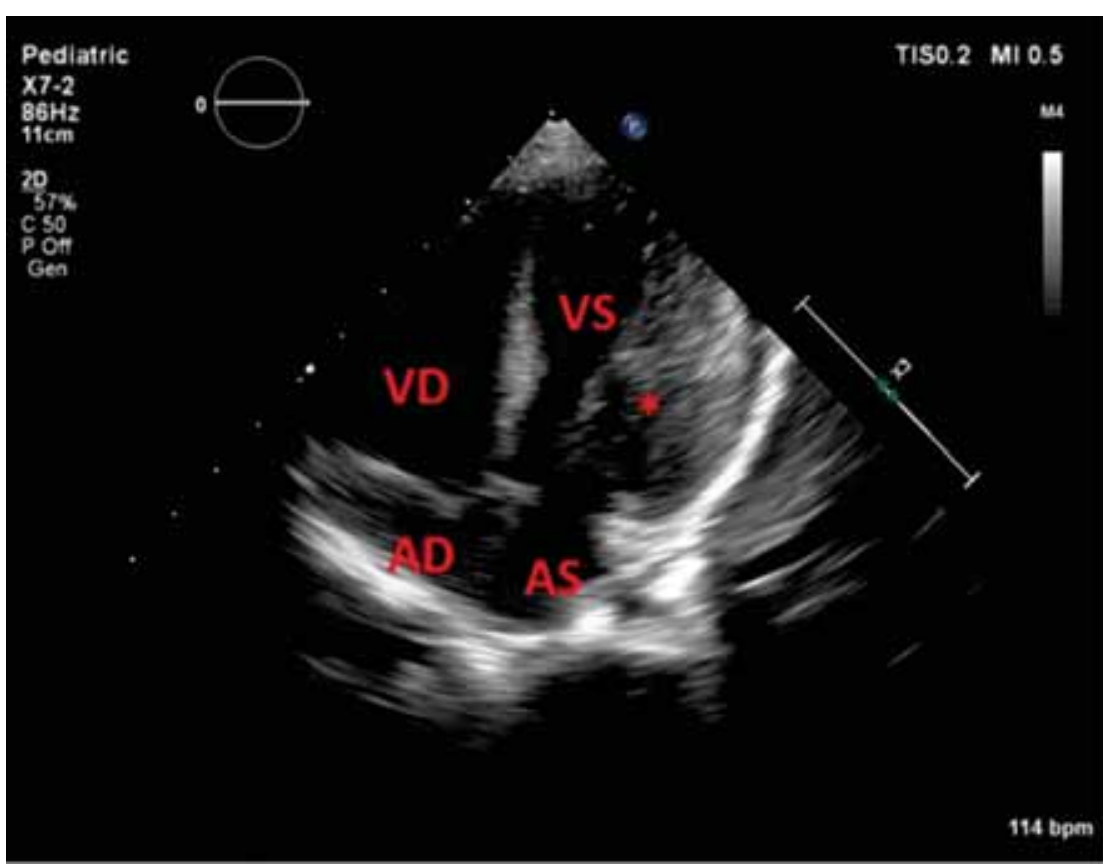

FIGURA 1. Ecocardiogramă $2 D$ - hipertrofie asimetrică

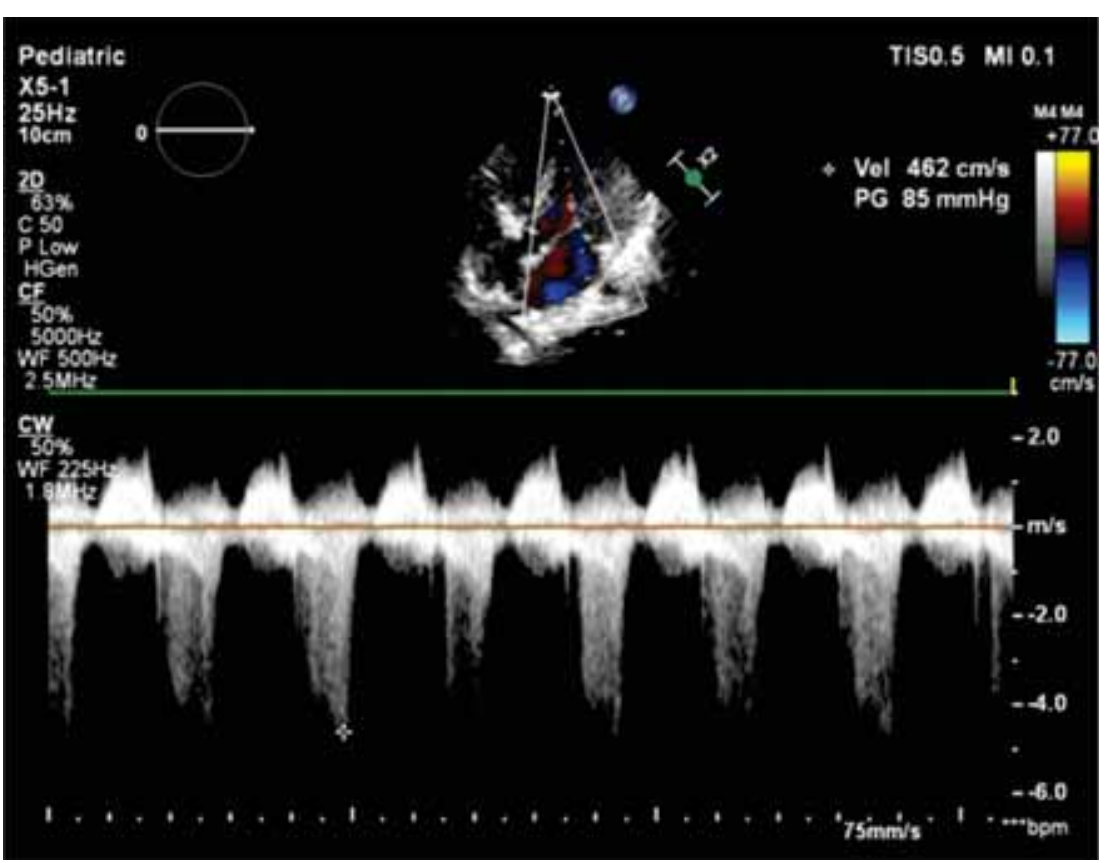

FIGURA 2. Interogare Doppler continuu, din apical 5 camere prezentând obstrucția dinamică a tractului de ejecție ventricular stâng 
De asemenea, s-au decelat valori crescute ale enzimelor serice musculare: creatinkinaza (CK) şi lactat dehidrogenaza (LDH): CK 390-680 U/1 (de 4 ori valoarea normală) şi LDH 1021-2224 U/1 (de 5 ori valoarea normală). Aceste valori crescute ale enzimelor serice se mențin ridicate în monitorizarea ulterioară (pe parcursul celor doi ani, de când pacientul este în evidența Clinicii de cardiologie pediatrică), în ciuda stabilității hemodinamice, a stării generale bune a copilului şi a tratamentului instituit: betablocante (Propranolol) pentru controlul obstrucției medioventriculare şi hepatoprotectoare - aspartat de arginină - Sargenor, aminoacizi - Aminosteril-N Hepa, complex de aminoacizi şi vitamine - Aspatofort şi suplimente naturale (hepatoprotector herbomineral) - Liv 52.

Pentru excluderea altor cauze implicate în etiologia sindromului de citoliză, pacientul a fost transferat în Clinica de Pediatrie $1 \mathrm{Tg}$. Mureş, unde au fost efectuate determinări serologice pentru virusurile hepatitice A, B şi C, virusul Epstein-Barr, citomegalovirus şi herpes virus, care au fost negative. Testele hematologice au exclus existența unor patologii din această sferă - talasemia, anemia hemolitică - şi au fost excluse bolile parazitare (inclusiv toxoplasmoza). Evaluarea pentru excluderea distrofiei musculare progresive a fost efectuată la Clinica de Neurologie Pediatrică „Alexandru Obregia“ din Bucureşti, testele genetice infirmând o distrofinopatie - distrofia musculară Duchenne şi bolile de stocaj a glicogenului, de tip II - boala Pompe.

Au mai rămas cateva posibile etiologii ale acestui sindrom de citoliză musculară, pe care am reuşit să le excludem, prin mijloace clinice şi paraclinice: patologiile endocrinologice, neoplasm (leucemia acută), bolile de piele, care pot fi însoțite de un nivel fals crescut al LDH-ului, şocul şi anoxia, injecțiile intramusculare repetate, administrarea anumitor medicamente care pot creşte nivelul seric al LDH-ului: aspirina, codeina sau vitamina A.

S-a efectuat, de asemenea, şi analiza profilului de acilcarnitină, fiind cunoscut faptul că deficitul de carnitină poate cauza cardiomiopatie hipertrofică / dilatativă.

\section{DISCUŢII}

Majoritatea studiilor arată că prognosticul în CMH este determinat de tipul de boală (obstructivă sau nonobstructivă), de prezența deficitelor genetice şi de identificarea aritmiilor cardiace amenință- toare de viață (4-6). În prezența unei CMH, un sindrom de citoliză sever, cu evoluţie progresivă şi persistentă, impune o monitorizare atentă pentru excluderea altor patologii noncardiace asociate $(7,8)$. Pentru pacientul nostru, testele genetice au permis excluderea distrofiei musculare Duchenne şi a bolilor de stocaj a glicogenului, de tip II - boala Pompe.

Dificultatea acestui caz a constat în încadrarea corectă a etiologiei sindromului de citoliză şi stabilirea ponderii afecțiunii cardiace în această ecuație.

Pacientul, din punct de vedere cardiac, a avut o evoluție favorabilă sub tratament betablocant, fără agravarea în timp a parametrilor ecocardiografici şi a statusului hemodinamic.

Este deja cunoscut faptul că enzima creatinkinaza există în relativ puține organe, fiind utilizată ca indice specific al leziunilor miocardului sau altor muşchi. Conform unui studiu efectuat de Swei H. Tsung pe un lot de 70 de pacienţi, deşi există dovezi de activitate a aceastei enzime şi în alte țesuturi specifice, se raportează activitatea cea mai intensă la nivelul muşchiului scheletic sau al miocardului (9).

Înainte de inițierea investigațiilor invazive (biopsie de miocard şi de muşchi scheletic), s-a analizat profilul celor 5 izoenzime ale lactat dehidrogenazei, deoarece fracționarea activității LDH-ului conduce la sporirea valorii sale diagnostice. Primele două izoenzime sunt elocvente pentru patologia cardiacă, izoenzima 3 pentru injuria pulmonară şi 4,5 pentru afectarea hepatică (10). Rezultatele testului pentru pacientul nostru au pus în evidență prima izoenzimă cu valori peste valoarea normală (VN): 44,7\% (VN 31\%), specifice atingerii cardiace.

În prezența unui sindrom de citoliză sever, se pune problema diagnosticului diferențial între patologia cardiacă şi rabdomioliză; caracterul progresiv şi persistent al acestui sindrom obligă la lărgirea investigațiilor şi rămâne o necunoscută pentru prognosticul afecțiunii de bază.

Particularitatea acestui caz constă în discordanţa dintre sindromul sever de citoliză musculară şi prezentarea clinică paucisimptomatică a unui copil cu $\mathrm{CMH}$.

\section{CONCLUZII}

Sindromul de citoliză sever şi persistent la un copil cu CMH cu stabilitate hemodinamică necesită o monitorizare atentă, putând anticipa un prognostic imprevizibil 